overriding controls.

Crepet considers the reversion from insect- to wind-pollination in the catkinbearing trees early in the history of flowering plants. This apparently occurred in the seasonally dry tropics, so that the present-day association of this group with temperate deciduous forest is misleading as a guide to its origin. Wolfe examines the Late Tertiary replacement of broad-leaved forest by conifers in the Pacific north-west. For those overwhelmed by the complex interactions of environmental factors, it is refreshing to learn that the "sole factor" in the assumption of dominance by conifers in that region was the declining summer temperature.

Perhaps the most far-reaching contribution is Schopf's reconciliation of molecular and palaeontological approaches to evolution. $\mathrm{He}$ concludes that "speciation may be so instantaneous geologically that many such events might well occur within the best possible resolution of the fossil record"'. He argues that even if our record of past life is the product of gradualistic change, the process of its formation puts its own punctuated stamp upon the picture. Which brings us, appropriately, back to Darwin's reservation over the "imperfections" of the fossil record.

W. G. Chaloner is Professor of Botany at Bedford College, University of London.

\section{Room for giants}

\author{
Janet V. Watson
}

Igneous Rocks of the British Isles. Edited by D.S. Sutherland. Pp.645. ISBN 0-471-27810-6. (Wiley: 1982.) £55, \$132.

FOR more than three thousand million years, melting in the outermost parts of the Earth has been an unusual event taking place only when and where temperatures rose to abnormally high levels. Igneous rocks formed by the consolidation of silicate melts therefore appear in the geological record as indicators of anomalous disturbances which are almost always related in time and space to major structural changes in the Earth's crust and mantle.

A book designed to document the record of igneous activity in the British Isles must therefore aim to throw light on the dynamic evolution of the entire crustal province if it is to be more than a source-book. From many points of view, there is a real need for a work of this kind. As Dr Sutherland notes in her editorial preface, no general synthesis has been published since Geikie's Ancient Volcanoes of Britain appeared in 1897. The literature which has accumulated since that date is vast, chaotic and often contradictory. Embedded in it are the outlines of fundamental ideas on the genesis, differentiation and emplacement of magmas which have become classics used all over the world. Encouraged as much by the exceptionally attractive dustjacket as by the table of contents, geologists will therefore open this book with thankfulness and hope.

Much care has been taken to make it as useful as possible as a work of reference. The treatment is broadly chronological and each of the seven parts opens with a general scene-setting chapter. The distribution of igneous suites and the structure of individual complexes are recorded in many clear maps, well-designed for their purpose. The descriptive chapters conform to a fairly consistent pattern which makes for ease of reference. Chemical analyses, geochronological data and petrographical details are segregated in appendices (the petrographical appendix living up to a hallowed tradition that goes back to J.J.H. Teall). All these are excellent features, due, no doubt, to good planning and editing.

The contents of the descriptive chapters vary in scope and style according to the kind of information available and the predilections of individual authors. The Tertiary province comes off best, with a cluster of chapters covering the volcanics, the centres, the dykes and the petrogenetic story collectively building up a coherent picture in which details fall easily into place. Elsewhere, there are some unexpected gaps (why does the bestexposed British ophiolite, in Shetland, rate only a passing mention?) and a number of thin patches not all of which can be put down to paucity of evidence.

More disturbing, however, is the apparent shapelessness of the sections covering the central event of British geological history, the Caledonian orogenic cycle. The decision to deal separately with volcanic and "plutonic" assemblages bears especially hard on these sections where the progression of tectonic events through subduction to collision and uplift is almost lost sight of. Though defensible in terms of convenience, the separation leads to absurdities such as the allocation of the Glencoe ring complex and the ignimbrites erupted in this complex during cauldron subsidence not only to different chapters but even to different parts. The British Caledonides emerge from this book as untidily as they do in the field. One longs in vain for the authoritative touch that might have shaken this sprawling orogen into shape. The Tertiary province has never lacked giants who measured up to its challenges. There is still, on the evidence of this book, something left for giants to do in the older parts of Britain.

Janet Watson is a Professor in the Department of Geology at Imperial College, University of London.

\section{Peat and prehistory}

\author{
A. G. Smith
}

The Archives of the Peat Bogs. By Sir Harry Godwin. Pp.229. ISBN 0-521-23784-X. (Cambridge University Press: 1981.) £25, $\$ 49.50$.

IT HAS probably come as a surprise to many a young scientist to realize that scientific work is as much about people as it is about science. This is amply illustrated in Sir Harry Godwin's book. It is also an adventure story. Through it all runs a sense of compelling interest and excitement. Above all, however, the author illustrates the way in which ideas about the nature and importance of peat bogs have flowed down the generations of scientists. It becomes, incidentally, an interesting contribution to the history of science.

In 1935 we find Godwin confessing "my ignorance of bog ecology was vast". But he began to learn his trade in the "magical Irish countryside"' (acting as chauffeur of a model $T$ Ford) on an excursion to Ireland with Hugo Oswald and A. G. Tansley. They chanced to meet, in Roundstone, another group including Knud Jessen, the great Danish Quaternary scientist, and one of his students, G. F. Mitchell. This group had just embarked on their studies of Irish bogs. We are treated to an enduring cameo of one of the fruits of this meeting: the party slowly sinking into the mire as they listened to an apparently interminable discussion between Jessen and Oswald, in interminable Irish rain, on Von Post's concept of soligenous bog.

From this encounter came the idea among the younger workers of pooling their experience to work on an uninvestigated British peat bog. Thus in 1936 began the classical work on the stratigraphy and ecology of Tregaron Bog in Dyfed, now a National Nature Reserve, which is briefly reviewed. The story continues with Godwin's adventures in the Somerset Levels and Borth Bog (Cors Fochno), Dyfed. The first scientific investigation of this now famous bog (again a National Nature Reserve) was apparently nearly frustrated by the presence of a wide drain. Having thrown their impedimenta over it, Godwin and his companion (D. H. Valentine) had no alternative but to undress and swim for it.

It is apparent that Harry Godwin soon fell in love with British peat bogs, not only as archives, but because of their flora. This he affectionately describes, treating the various species as the dramatis personae of the historical pageant. In his descriptions of the bog plants he takes care to show how they can still be recognized after their preservation in the peat. These tricks of the trade are one of the many valuable sidelights of the book.

The ability to recognize the sub-fossil remains of bog plants is of course of fundamental importance in understanding 